\title{
Ana Porrúa
}

\section{LA PIEL ${ }^{\mathrm{II}}$}

Imposible pelar una araña, un gusano que hace seda, una ballena, una mariposa. Hay pieles que mueren amorosamente adheridas a los cuerpos. Responden a una rara y perfecta simetría.

(ars arrandi)

\section{I}

¿y si debajo de ésta

hay otra piel?

¿una tersa tela que cubra

músculos y sangre y ligamentos

y haya ignorado

el movimiento del amor ido?
2
si pudiera dejar mi rostro
terso como la piel de una cala
o un pétalo de blanca rosa.
si fuera o fuese posible
una piel sin historia/
puro jardín o huerto.

II In: La piel (inédito) 
3

imposible/ sin embargo

el arabesco

el repujado de pétalos

que exhibe la Flora de Arcimboldo

en inquietante perfil.

4

imposible el arte

después del abandono.

sólo la tecnología avanza

iluminada.

5

la espuma no será pétalo

pero cubre

los tramos oscuros

de la piel en bello artificio.

primero el mentón luego las cejas

'arcoiris del ojo'/

el filo pasa agudo y labra

otra forma del dolor.

6

el rostro liso:

una sábana almidonada

o una tela que se prepara

para soportar el peso de los óleos. 